\title{
Incesto e saúde mental: uma compreensão psicanalítica sobre a dinâmica das famílias incestuosas
}

\author{
Incest and mental health: a psychoanalytical compreension \\ about the dynamics of incestuous families
}

\author{
Gisele Joana Gobbetti
}

Gobetti GJ. Incesto e saúde mental: uma compreensão psicanalítica sobre a dinâmica das famílias incestuosas [Resumo]. Saúde, Ética \& Justiça, São Paulo. 2003;8(1/2):66-7.

\begin{abstract}
RESUMO: A possibilidade da transgressao da lei máxima que rege a nossa cultura é um fator inquietante. O incesto, ao mesmo tempo em que atrai nossa atenção, é um tema que causa resistência a reflexões por abarcar um desejo presente em todo ser humano. Segundo os estruturalistas, a interdição do incesto é um fator culturale necessário para o desenvolvimento psico-social do indivíduo. De acordo com a Psicanálise, a não atuação do incesto favorece a estruturação do aparelho mental ld, ego e superego. O presente estudo tem como objetivo ampliar a compreensão sobre o tema, visando a observação da dinâmica das famílias onde esta interdição não ocorreu, já que o incesto abarca estes dois conceitos: família e abuso sexual. A metodologia utilizada foi a avaliação de dados obtidos pela autora no seu trabalho em um serviço de atendimento a famílias incestuosas (CEARAS - Centro de Estudos e Atendimento Relativos ao Abuso Sexual - Faculdade de Medicina da USP). Estes dados referem-se a: grau de parentesco entre as pessoas diretamente envolvidas na relação sexual, tipo de relação incestuosa, duração da relação e por quem foi feita a denúncia. Uma avaliação qualitativa destes dados foi completada por estudos de caso com material clínico de quatro atendimentos familiares. A teoria utilizada para a compreensão destes fenômenos foi a psicanalítica. Na relação incestuosa, foi percebido que existe o envolvimento, direto ou indireto, de todos os membros da família e que a violência do incesto não pode ser traduzida apenas pela relação sexual, mas principalmente pela não diferenciação das funções familiares.
\end{abstract}

DESCRITORES: Incesto/psicologia. Saúde mental. Relações familiares. Violência doméstica/psicologia. Terapia familiar. Serviços de saúde mental.

Dissertação de mestrado apresentada a Faculdade de Medicina da Universidade de São Paulo, defesa em 2000. Orientador: Cláudio Cohen.

Endereço para correspondência: Gisele Gobetti. Rua Teodoro Sampaio, 115 - CEP 005405-000 São Paulo, SP. 
Gobetti, G. J. Incesto e saúde mental : uma compreensão psicanalítica sobre a dinâmica das famílias. [Resumo].

Gobetti GJ. Incest and mental health: a psychoanalytical compreension about the dynamics of incestuous families [Abstract]. Saúde, Ética \& Justiça, São Paulo. 2003;8(1/2):66-7.

ABSTRACT: The possibility of transgression of the maxim law in our culture is an anguishing factor. In the same way that the incest attracts attention, it cause ressistance to formulate reflections about a inherent desire in all humans beings. The interdiction of the incest is a cultural and necessary factor for social and psychological development. In the psychoanalytic approach, sexual relationships among family members don't permit the mental development. The incest makes reference to both concepts: sexual abuse and family. In this sense, the purpose of this study was to contribute to the knowledge of this issue through the observation of the dinamics of incestuous families in which there was not interdiction. The methodology includes analyzed data (parentage level among people directly envolved in incestuous relationships, type, duration and denounce of the relationships) and cases studies by author in her work of treatment for incestuous families comming from Court in CEARAS (Center of Studies and Treatment for Sexual Abuse - Medical School of the São Paulo University - USP). It was noted that there is the involvement of all family members, directly or indirectly, in incestuous relations and the violence of incest may be found in the confusion of familial functions more than in sexual relationship.

KEY WORDS: Incest/psychology. Mental health. Family relations. Domestic violence. Family therapy. Mental health services. 